\title{
Polish Stress Echocardiography Registry (Pol-STRESS registry) - a multicentre study. Stress echocardiography in Poland: numbers, settings, results, and complications
}

\author{
Edyta Płońska-Gościniak ${ }^{1}$, Jarosław D. Kasprzak ${ }^{2}$, Szymon Olędzki ${ }^{1}$, Jolanta Rzucidło-Resil ${ }^{3}$, \\ Piotr Gościniak ${ }^{4}$, Tomasz Kukulski ${ }^{5}$, Katarzyna Mizia-Stec ${ }^{6}$, Wojciech Kosmala ${ }^{7}$, Dariusz Kosior ${ }^{8}$, \\ Marta Marcinkiewicz-Siemion ${ }^{9}$, Barbara Brzezińska ${ }^{10}$, Beata Zaborska ${ }^{11}$, Marcin Fijałkowski ${ }^{12}$, \\ Iwona Świątkiewicz ${ }^{13}$, Andrzej Szyszka ${ }^{14}$, Jan Błażejewski ${ }^{15}$, Wojciech Witkiewicz ${ }^{1}$, \\ Danuta Sorysz ${ }^{16}$, Agnieszka Olszanecka ${ }^{17}$, Zbigniew Gąsior ${ }^{5}$ \\ ${ }^{1}$ Coordinator; Department of Cardiology, Pomeranian Medical University, Szczecin, Poland \\ 2Department of Cardiology, Medical University of Lodz, Lodz, Poland \\ ${ }^{3}$ Department of Coronary Artery Disease, John Paul II Hospital, Jagiellonian University, Medical College, Krakow, Poland \\ ${ }^{4}$ Department of Cardiology, Provincial Hospital, Szczecin, Poland \\ ${ }^{5}$ Department of Cardiology, Medical University of Silesia in Katowice, Silesian Centre for Heart Disease, Zabrze, Poland \\ ${ }^{6} 1^{\text {st }}$ Department of Cardiology, School of Medicine in Katowice, Medical University of Silesia, Katowice, Poland \\ 'Department of Cardiology, Wroclaw Medical University, Wroclaw, Poland \\ ${ }^{8}$ Department of Cardiology, Central University Hospital, Warsaw, Poland \\ ${ }^{9}$ Department of Cardiology, University Hospital, Bialystok, Poland \\ ${ }^{10}$ Department of Cardiology, T. Marciniak Hospital, Wroclaw, Poland \\ ${ }^{11}$ Department of Cardiology, Postgraduate Medical School, Grochowski Hospital, Warsaw, Poland \\ $121^{\text {st }}$ Department of Cardiology, Medical University of Gdansk, Gdansk, Poland \\ ${ }^{13}$ Department of Cardiology and Internal Medicine, Collegium Medicum of Nicolaus Copernicus University, Bydgoszcz, Poland \\ ${ }^{14} 2^{\text {nd }}$ Department of Cardiology, Poznan University of Medical Sciences, Poznan, Poland \\ ${ }^{15} 2^{\text {nd }}$ Chair of Cardiology, UMK, Collegium Medicum, Bydgoszcz, Poland \\ ${ }^{16} 2^{\text {nd }}$ Department of Cardiology, Jagiellonian University Medical College, Krakow, Poland \\ $171^{\text {st }}$ Department of Cardiology, Interventional Electrocardiology, and Hypertension, Jagiellonian University Medical College, Krakow, Poland
}

\section{Abstract}

Background: Stress echocardiography (SE) is widely used in Europe. No collective data have been available on the use of SE in Poland until now.

Aim: To evaluate the number of SE investigations performed in Poland, their settings, complications, and results.

Methods: In this retrospective survey, referral cardiology centres in Poland were asked to fill in a questionnaire regarding SE examinations performed from May 1, 2014 to May 1, 2015.

Results: The study included data from 17 university hospitals and large community hospitals, which performed 4611 SE examinations, including 4408 tests in patients investigated for coronary artery disease (CAD) and 203 tests to evaluate valvular heart disease (VHD). To evaluate CAD, all centres performed dobutamine SE (100\%), 10 centres performed pacing SE (58.8\%), while cycle ergometer SE and treadmill SE were performed by six (35.3\%) and five $(29.4 \%)$ centres, respectively. Dipyridamole SE was performed in one centre. All evaluated centres (100\%) performed SE to evaluate low-flow/low-gradient aortic

Address for correspondence:

Szymon Olędzki, MD, Department of Cardiology, Pomeranian Medical University, ul. Powstańców Wielkopolskich 72, 70-111 Szczecin, Poland, e-mail: soledzki@gmail.com

Received: 25.11.2016 Accepted: 12.06.2017

Available as AoP: 28.06.2017

Kardiologia Polska Copyright (C) Polskie Towarzystwo Kardiologiczne 2017 
stenosis, eight (47\%) performed SE to evaluate asymptomatic aortic stenosis, and also eight (47\%) performed SE to evaluate mitral regurgitation. The mean number of examinations per year was 271 per centre. Most centres performed more than 100 examinations per year (11 centres, $64.7 \%$ ). We did not identify any cardiac death during SE examination in any of the centres. Myocardial infarction occurred in three (0.07\%) patients. Non-sustained ventricular tachycardia occurred in $52(1.1 \%)$ SE examinations. The rates of minor complications were low. SE to evaluate CAD was more commonly performed in the hospital settings using cycle ergometer (72.6\%), treadmill (87.6\%), and low-dose dobutamine (68.0\%), while a dipyridamole test was more frequently employed in ambulatory patients (77.6\%). No significant differences between the rates of examinations performed in the ambulatory and hospital settings were found for high-dose dobutamine and pacing SE. Examinations to evaluate VHD were significantly more frequently performed in the hospital settings. SE examinations accounted for more than one third of all stress tests performed in the surveyed centres over the study period.

Conclusions: Stress echocardiography is a safe diagnostic method, and major complications are very rare. Despite European recommendations, SE examinations to evaluate CAD are performed less frequently than electrocardiographic exercise tests, although they already comprise a significant proportion of all stress tests. It seems reasonable to promote SE further for the evaluation of both CAD and VHD.

Key words: stress echocardiography, valvular heart disease, coronary artery disease

Kardiol Pol 2017; 75, 9: 922-930

\section{INTRODUCTION}

Stress echocardiography (SE) is an established diagnostic method most commonly used to detect myocardial ischaemia in patients with suspected stable coronary artery disease (CAD). The test is usually performed in patients with an intermediate pre-test likelihood of CAD to evaluate indications for invasive testing. The sensitivity and specificity of SE for the diagnosis of significant obstructive CAD is high. In addition, the diagnostic value of SE is improved by the use of a contrast agent or new echocardiographic techniques (tissue Doppler echocardiography-strain, strain rate, and myocardial velocity imaging) $[1,2]$. SE is also used to evaluate myocardial viability before coronary revascularisation to predict left ventricular systolic function improvement following coronary revascularisation. SE may also be considered in CAD patients following invasive testing to evaluate the significance of coronary lesions if the angiographic findings are not clearly suggestive of benefits of interventional treatment. SE is also indicated in patients after coronary intervention in case of recurrent CAD symptoms or doubts regarding the need for another stage of coronary revascularisation. In addition, SE is used for functional evaluation of valvular heart disease (VHD), most commonly aortic stenosis (AS) and mitral regurgitation (MR), if resting echocardiographic findings are unclear or inconsistent with the clinical presentation. Due to these extensive diagnostic capabilities, SE is widely used in Poland and Europe, although it is technically demanding and requires an experienced echocardiographer.

Until now, no collective data have been available on the use of SE in Poland. A report by the European Association of Cardiovascular Imaging (EACVI) indicates that cardiovascular imaging registries operate in few countries [3]. As highlighted by the EACVI experts, knowledge regarding non-invasive cardiac imaging use, including SE, is important for further dissemination of these diagnostic modalities, better standardisation of diagnostic testing in Europe, and improved diagnostic value of non-invasive testing [3]. The only SE registry in Europe has been reported in the United Kingdom (UK) [1].

In the present paper, we present the results of the first Polish SE (Pol-STRESS) registry, which included 17 large university and regional hospitals. We evaluated the number and settings of SE investigations performed in these centres, indications for testing, types and the number of specific tests, their results, the rate of non-diagnostic investigations, and the rates and types of complications. The study was a retrospective voluntary survey. All invited centres took part in the registry.

\section{METHODS}

In this first Polish retrospective SE survey, tertiary care cardiology centres in Poland were asked to fill in a questionnaire regarding SE examinations, electrocardiographic exercise tests, and coronary angiographies performed from May 1, 2014 to May 1, 2015. The study was initiated under the auspices of the Clinical Initiative Committee of the Board of the Polish Cardiac Society (PCS). The majority of the Polish medical university centres where the studies were performed exclusively by cardiologists experienced in SE were invited to participate in the survey. Requirements related to equipment standards and operator experience have been specified by the Echocardiography Working Group of the PCS and the appropriate national certification documents.

\section{RESULTS}

\section{Overall centre characteristics}

We report the results of a one-year registry of SE examinations conducted in 17 university hospitals and large community hospitals. All the questions of the questionnaire were answered by all the centres. We collected the data from 4611 SE examinations, including 4408 tests in patients investigated for CAD 


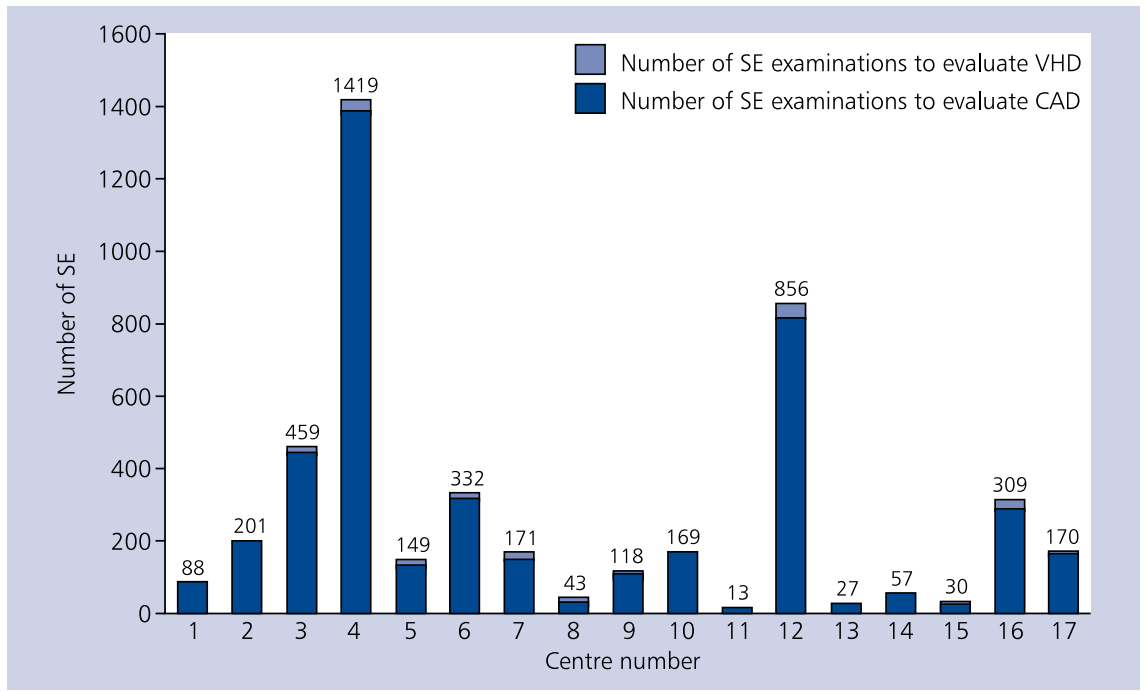

Figure 1. Number of stress echocardiography (SE) examinations performed in the study centres; CAD — coronary artery disease; VHD — valvular heart disease

(moderate probability of a significant disease) and 203 tests to evaluate VHD (low-flow/low-gradient aortic stenosis [LFLG-AS], asymptomatic AS, and MR). In comparison, during the same period 20,637 invasive coronary angiographies and 9118 electrocardiographic exercise tests were performed in the surveyed centres.

Indications for SE included the investigation of CAD and $\mathrm{VHD}$ in all centres. To evaluate CAD, dobutamine SE (all 17 centres, 100\%) and pacing SE (10 centres, 58.8\%) were the most commonly used tests, followed by cycle ergometer SE (six centres, 35.3\%) and treadmill SE (five centres, 29.4\%). Dipyridamole SE was performed in only one centre. All evaluated centres (100\%) performed SE to evaluate LFLG-AS, eight $(47 \%)$ performed SE to evaluate asymptomatic AS, and eight (47\%) performed SE to evaluate MR. The questionnaire did not include specific questions on the aetiology of MR. All SE examinations were performed in accordance with the European Society of Cardiology (ESC) recommendations [4, 5]. The number of examinations performed ranged from 13 to 1419 per year, mean 271/year. Most centres performed more than 100 examinations per year (11 centres, 64.7\%), and $13(76.5 \%)$ centres performed more than 50 examinations per year (Fig. 1). Most centres ( $n=14,82.4 \%$ ) performed at least two types of tests, most commonly dobutamine and pacing SE. Examinations were performed by cardiologists.

\section{Types and the number of SE examinations}

The types and the number of specific tests performed in the study centres overall, to evaluate VHD, and to evaluate CAD are shown in Table 1 and Figures 2 and 3.

Diagnostic and non-diagnostic SE examinations Precise data regarding the test results were unavailable for 248 (5.6\%) of 4408 SE examinations performed to evaluate
Table 1. Number of stress echo examinations performed to evaluate coronary artery disease (CAD) and valvular heart disease $(\mathrm{VHD})$

\begin{tabular}{|lc|}
\hline Stress echo test type & $\begin{array}{c}\text { No. (\%) } \\
\text { of examinations } \\
\text { ( } \mathbf{n}=4611)\end{array}$ \\
\hline Evaluation of CAD: & \\
Cycle ergometer & $73(1.58 \%)$ \\
Treadmill & $1439(31.2 \%)$ \\
High-dose dobutamine & $2253(48.86 \%)$ \\
Low-dose dobutamine & $415(9.0 \%)$ \\
Dipyridamole & $49(1.06 \%)$ \\
Pacing & $179(3.9 \%)$ \\
Evaluation of VHD: & \\
Asymptomatic aortic stenosis & $52(1.13 \%)$ \\
Low-flow/low-gradient aortic stenosis & $112(2.43 \%)$ \\
Mitral regurgitation/other & $39(0.85 \%)$ \\
\hline
\end{tabular}

CAD. Of the remaining 4160 examinations, a diagnostic result was obtained in $86.6 \%$ of cases (a positive result in $27.9 \%$ of cases and a negative result in $58.8 \%$ of cases), and a non-diagnostic result was obtained in $13.2 \%$ of cases. Data on the number of positive, negative, and non-diagnostic results of specific test types are shown in Table 2.

Of 203 SE examinations performed to evaluate VHD, a non-diagnostic test result was obtained in only one $(0.49 \%)$ patient, and the result was not available for three $(1.48 \%)$ tests. Among patients with asymptomatic AS, a positive result (symptoms) was obtained in $53.9 \%$, and a negative result in 46.1\%. Among patients with LFLG-AS, severe AS was identi- 


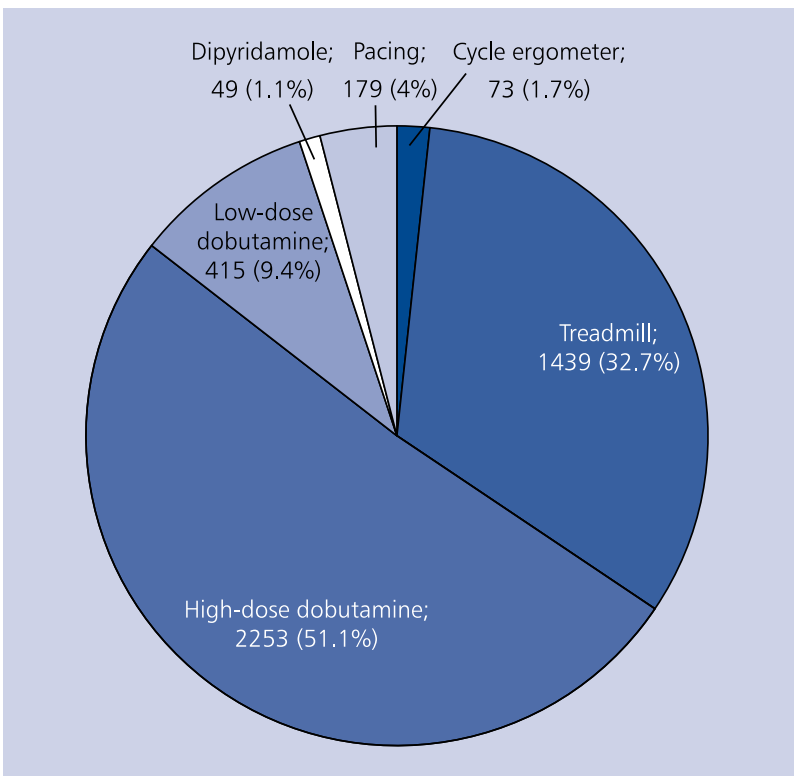

Figure 2. Number of stress echo examinations performed to evaluate coronary artery disease $(n=4408)$

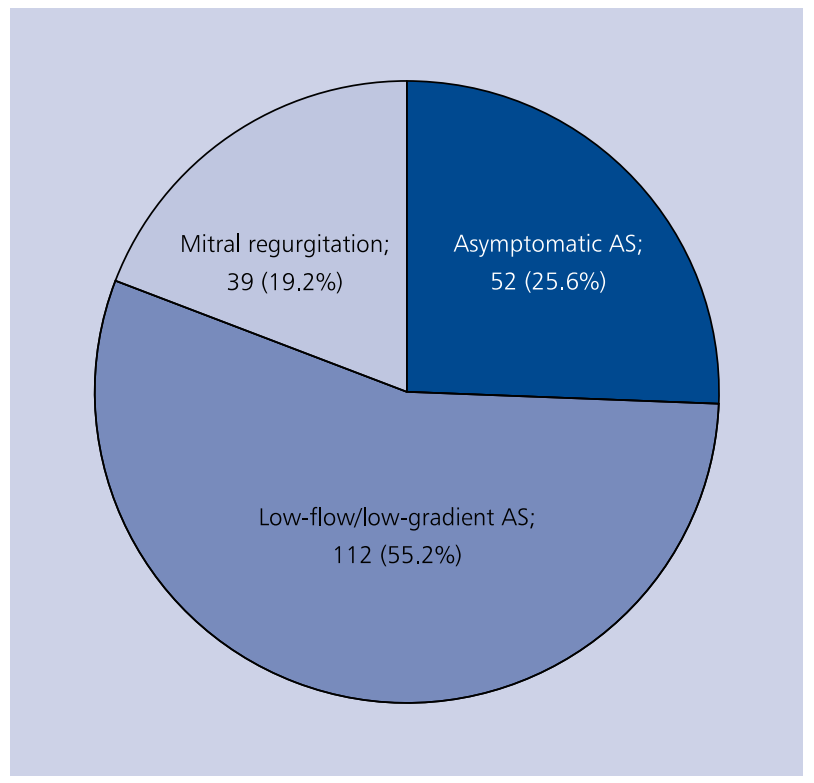

Figure 3. Number of stress echo examinations performed to evaluate valvular heart disease $(n=203)$; AS - aortic stenosis

Table 2. Results of stress echo examinations performed to evaluate coronary artery disease

\begin{tabular}{|c|c|c|c|}
\hline $\begin{array}{l}\text { Test type and the number } \\
\text { of examinations }(n=4160)\end{array}$ & $\begin{array}{l}\text { No. }(\%) \text { of positive } \\
\text { test results } \\
(n=1162)\end{array}$ & $\begin{array}{l}\text { No. (\%) of negative } \\
\text { test results } \\
(n=2448)\end{array}$ & $\begin{array}{c}\text { No. }(\%) \text { of non-diagnostic } \\
\text { test results } \\
(n=550)\end{array}$ \\
\hline Cycle ergometer $(n=73)$ & $16(21.9 \%)$ & $46(63 \%)$ & $11(15.1 \%)$ \\
\hline Treadmill $(n=1416)$ & $478(33.8 \%)$ & $651(46 \%)$ & $287(20.2 \%)$ \\
\hline High-dose dobutamine $(n=2068)$ & $460(22.2 \%)$ & $1385(67 \%)$ & $223(10.8 \%)$ \\
\hline Low-dose dobutamine $(\mathrm{n}=385)$ & $145(37.7 \%)$ & $213(55.3 \%)$ & $27(7 \%)$ \\
\hline Dipyridamole $(n=39)$ & $15(30.6 \%)$ & $24(49 \%)$ & - \\
\hline Pacing $(n=179)$ & $48(26.8 \%)$ & $129(72 \%)$ & $2(1.1 \%)$ \\
\hline
\end{tabular}

fied in $60.7 \%$. Severe MR was confirmed in $27.8 \%$ of patients evaluated for this form of VHD.

\section{Stress echo settings}

In the hospital setting, SE to evaluate CAD was more commonly performed using cycle ergometer $(72.6 \%)$, treadmill $(87.6 \%)$, and low-dose dobutamine $(68.0 \%)$, while dipyridamole test was more frequently applied in the ambulatory patients (77.6\%). No significant differences between the rates of examinations performed in the ambulatory and hospital setting were found for high-dose dobutamine and pacing SE. Examinations to evaluate VHD were significantly more frequently performed in the hospital settings (Fig. 4).

\section{Safety of echocardiographic stress testing}

The questionnaire included major and minor complications. In our one-year registry that included 4611 SE examinations; we did not record any cardiac death $(0 \%)$ during SE examination in any of the centres. Myocardial infarction as a complication of the test occurred in three $(0.07 \%)$ patients, including one case during treadmill SE and two cases during high-dose dobutamine SE. Non-sustained ventricular tachycardia occurred during 52 (1.1\%) SE examinations, including three cycle ergometer, nine treadmill, 28 high-dose dobutamine, and 12 low-dose dobutamine tests. No cases of ventricular tachycardia were reported during dipyridamole and pacing SE examinations. No major complications were noted during SE examinations performed to evaluate VHD.

Major SE complications that occurred during specific test types are summarised in Table 3. The safest test type was pacing $\mathrm{SE}$, and major complications were most frequent during cycle ergometer and high-dose dobutamine SE examinations.

\section{Minor complications of SE}

Minor complications of SE examinations included an asymptomatic increase in systolic blood pressure over 220 mm Hg or 


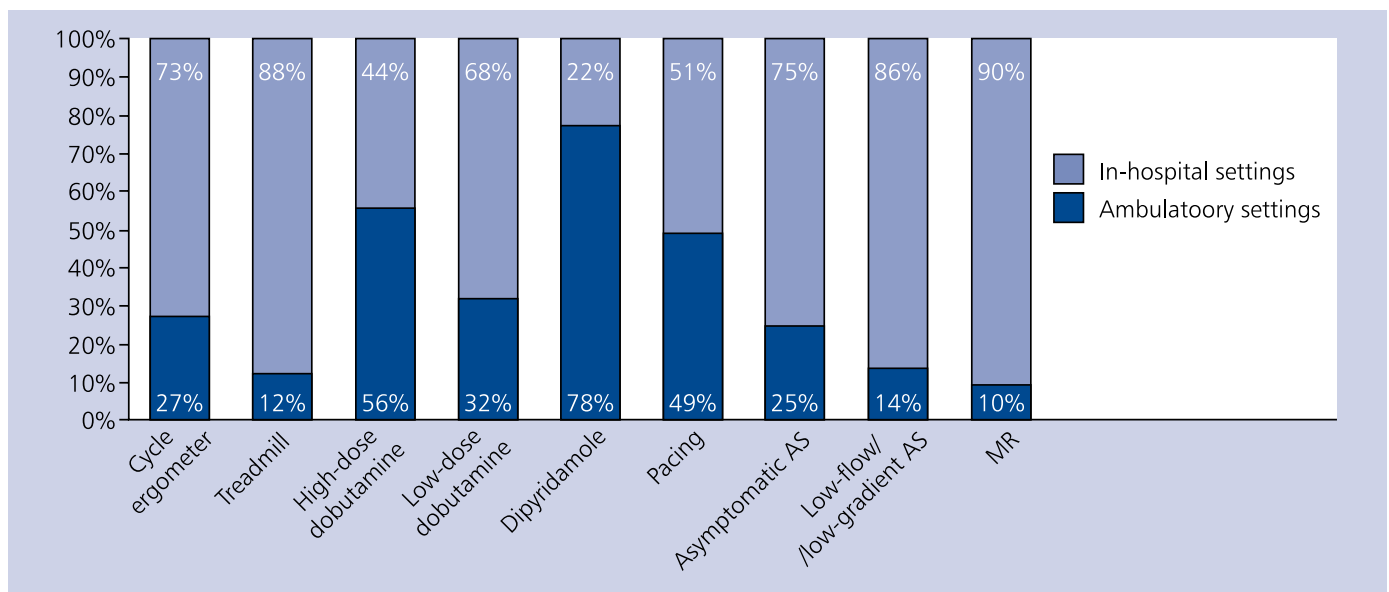

Figure 4. Stress echo settings in relation to indications and the test type; AS - aortic stenosis; MR - mitral regurgitation

Table 3. Major complications during stress echo examinations performed to evaluate coronary artery disease and valvular heart disease $(n=4611)$

\begin{tabular}{|c|c|c|c|}
\hline & Death (\%) & Myocardial infarction (\%) & Ventricular tachycardia (\%) \\
\hline Cycle ergometer $(n=73)$ & $0(0 \%)$ & $0(0 \%)$ & $3(4.11 \%)$ \\
\hline Treadmill $(n=1439)$ & $0(0 \%)$ & $1(0.07 \%)$ & $9(0.63 \%)$ \\
\hline High-dose dobutamine $(n=2253)$ & $0(0 \%)$ & $2(0.09 \%)$ & $28(1.24 \%)$ \\
\hline Low-dose dobutamine $(n=415)$ & $0(0 \%)$ & $0(0 \%)$ & $12(2.89 \%)$ \\
\hline Dipyridamole $(n=49)$ & $0(0 \%)$ & $0(0 \%)$ & $0(0 \%)$ \\
\hline Pacing $(n=179)$ & $0(0 \%)$ & $0(0 \%)$ & $0(0 \%)$ \\
\hline Asymptomatic aortic stenosis $(n=52)$ & $0(0 \%)$ & $0(0 \%)$ & $0(0 \%)$ \\
\hline Low-flow/low-gradient aortic stenosis $(n=112)$ & $0(0 \%)$ & $0(0 \%)$ & $0(0 \%)$ \\
\hline Mitral regurgitation $(n=39)$ & $0(0 \%)$ & $0(0 \%)$ & $0(0 \%)$ \\
\hline
\end{tabular}

decrease of at least $20 \mathrm{~mm} \mathrm{Hg}$, mild arrhythmia and conduction disturbances, chest discomfort, headache, nausea, anxiety, and palpitations. The rates of mild complications during specific test types are summarised in Table 4. Supraventricular arrhythmia occurred in only one $(0.49 \%)$ patient during SE to evaluate VHD (LFLG-AS).

\section{DISCUSSION}

The present study reports on the first multicentre Pol-STRESS registry of the usual clinical practice of SE in Poland. We collected data from 17 centres, which performed 4611 SE examinations over the period of one year. The median number of SE examinations in the surveyed centres was 169 per year. For comparison, in an analysis of data from 85 UK centres, the median number of SE examinations was about 400 per year [1]. Despite this difference between Poland and the UK, the number of SE examinations performed in Poland is large. While electrocardiographic exercise test remains the most commonly performed stress test in Poland, SE examinations accounted for more than one third of all stress tests performed in the surveyed centres over the study period. Due to superior
Table 4. Minor complications during stress echo examinations performed to evaluate coronary artery disease and valvular heart disease $(n=4611)$

\section{Minor complications (\%)}

\begin{tabular}{|lc|} 
Cycle ergometer $(n=73)$ & $10.96 \%$ \\
Treadmill $(n=1439)$ & $0.2 \%$ \\
High-dose dobutamine $(n=2253)$ & $6.3 \%$ \\
Low-dose dobutamine $(n=415)$ & $4.1 \%$ \\
Dipyridamole $(n=49)$ & $2 \%$ \\
Pacing $(n=179)$ & $0 \%$ \\
Asymptomatic AS $(n=52)$ & $0 \%$ \\
Low-flow/low-gradient AS $(n=112)$ & $0,9 \%$ \\
Mitral regurgitation $(n=39)$ & $0 \%$ \\
\hline
\end{tabular}

AS - aortic stenosis

sensitivity for detecting myocardial ischaemia, SE, myocardial perfusion scintigraphy, and stress cardiac magnetic resonance imaging are the recommended diagnostic tools to evaluate 
CAD $[4,5]$. It is likely that although the availability of stress imaging modalities remains low in many parts of Poland, in some cases the choice of the diagnostic method may be related more to the customary attitudes of physicians working in cardiology clinics than to the actual waiting time. Another important factor may be variation in the way the diagnostic tests are financed in various health care systems, including differences in the healthcare expenditure. As highlighted in the EACVI expert consensus, registries such as the reported one may positively affect the availability of non-invasive cardiac testing by promoting these methods among the healthcare community and policy-makers [3].

All surveyed centres performed SE examinations using high-dose dobutamine, and 11 (64.7\%) centres performed exercise SE examinations. This proportion is similar to that reported in the UK where exercise SE examinations were performed in $67 \%$ of echocardiography laboratories [1]. Dipyridamole SE examinations were performed in $7.1 \%$ of echocardiography laboratories in the UK [1] compared to $5.9 \%$ in our registry. Use of different SE methods in a single echocardiography laboratory is desirable as each patient requires an individual diagnostic approach and appropriate stress for a given clinical scenario, although the operator experience is also an important factor. As many as 10 (58.8\%) of the surveyed Polish echocardiography laboratories performed SE examinations using implantable cardiac pacing devices. As reported in the above-cited British registry, rapid pacing was employed for SE in $40 \%$ of UK centres [1]. SE using rapid pacing is accurate and safe but it may be more difficult to interpret in cases of ventricular pacing or the occurrence of the Wenckebach point below the target ventricular rate [2]. In addition, 16 (94\%) centres performed SE using low-dose dobutamine protocol. If myocardial viability is assessed and no major complications are seen during low-dose dobutamine infusion, it is recommended to continue the study, increasing the infusion rate to standard doses, which may disclose the biphasic ischaemic response [2].

The main indication for $\mathrm{SE}$ was $\mathrm{CAD}$, with evaluation for CAD performed in all centres. In addition, all centres in Poland also performed SE examinations to evaluate VHD, and such evaluation is performed in nearly all (98.8\%) UK centres [1]. The most common indication for SE to assess VHD was LFLG-AS. SE for this indication was performed in all Polish centres and in $95.3 \%$ of UK centres [1]. The number of studies performed for this indication may be expected to increase with the population aging and rising prevalence of AS. SE was performed to evaluate severe asymptomatic AS in eight (47\%) surveyed Polish centres, and eight centres performed SE to evaluate MR, a proportion which was similar to the UK data $(40 \%$ and $37.6 \%$ of centres, respectively) [1]. Of note, the number of SE examinations to evaluate VHD was low in relation to the number of studies performed to assess CAD.
About $13.2 \%$ of SE examinations performed to evaluate CAD were non-diagnostic, most commonly using treadmill and least frequently with pacing. This proportion might have been overestimated due to the retrospective nature of the study and data collection using a questionnaire. The most common reason for a non-diagnostic SE result is a failure to achieve target heart rate (with exercise testing) or dobutamine intolerance, and rarely it is due to poor imaging quality (when $\geq$ two adjacent segments cannot be visualised) [6]. In our registry, we did not evaluate the reasons for non-diagnostic test results. The evaluation of AS was associated with a marginal rate of non-diagnostic test results (due to adverse effects or the patient's request to terminate the test), and the non-diagnostic tests were not identified in patients evaluated for MR. The proportion of non-diagnostic test results reported in the literature varies, ranging from $5 \%$ to $20 \%$ in the case of exercise testing without the use of additional echocardiographic techniques $[7,8]$. Although it is associated with increased costs, the use of contrast agents decreases the number of non-diagnostic tests $[8-10]$.

$27.9 \%$ of tests performed to diagnose CAD confirmed myocardial ischaemia, with a varying proportion of positive test results depending on the test type. Although a detailed analysis of this issue is beyond the scope of the present study, it is likely that patients who underwent an exercise test differed from those subjected to the pharmacological stress. The latter group included patients in whom exercise was contraindicated or an exercise test was not feasible because of the advanced age or concomitant conditions. At the same time, as highlighted in the ESC guidelines [11], these patients often present with atypical symptoms. Literature data indicate a varying proportion of SE examinations positive for myocardial ischaemia $[6,12]$. We believe that even large randomised studies may not answer the question regarding the actual proportion of positive SE test results. Such data may only be provided by registries such as the present one, evaluating all patients subjected to SE during a specific time period. Randomised studies are based on specific inclusion and exclusion criteria to obtain a homogenous study population. Thus, the study participants are a selected group, which differs from the general population of patients encountered in the clinical practice. In contrast, our registry was free from such selection bias. Nevertheless, the overall proportion of positive and negative test results indicates that the SE examinations were performed in accordance with the ESC recommendations for patients with a moderate probability of CAD.

In patients with low-flow or asymptomatic AS, a positive result (occurrence of symptoms or an increase in cardiac output with haemodynamic parameters corresponding to severe AS, respectively) was noted in more than half of patients. Studies indicate that severe AS is present in $65-80 \%$ of patients with LFLG-AS $[13,14]$. This proportion mostly depends on the inclusion criteria. The surveyed centres performed SE 
examinations in accordance with the recommendations of the Echocardiography Section of the PCS [2]. The latter document is consistent with the ESC guidelines [15].

Literature data indicate that stress increases the severity of MR in about $30 \%$ of patients undergoing SE to evaluate MR [10], a figure similar to the proportion noted in our registry.

Overall, 224 complications of SE examination (4.9\% of all tests) were reported by the surveyed centres in the Pol-STRESS registry. No cases of mortality related to SE testing were identified. Three cases of SE-related myocardial infarction were reported in two $(11.7 \%)$ centres. In the cited UK registry, a fatal outcome of SE was reported by one (1.1\%) centre, and eight $(9.4 \%)$ centres reported at least one case of myocardial infarction due to SE testing. SE is considered a safe diagnostic modality, with the incidence of SE-related deaths estimated at $<0.01 \%$, and the incidence of myocardial infarction in the range $0.01-0.1 \%$ [16-18]. Other major complications such as neurological events, myocardial free wall rupture, and asystole are very rare [16] and were not reported to occur in the surveyed centres over the study period. Available literature data indicate that the incidence of ventricular arrhythmia during SE testing varies widely, from $0 \%$ to nearly $5 \%[16,17,19]$. In our registry, we found a low rate of SE examinations complicated by ventricular tachycardia. Mild complications were also infrequent.

Of note, a high proportion of tests was performed in hospital settings. Patients undergoing SE are mostly in a good or very good overall clinical condition. No data are available regarding SE settings in other countries.

\section{Limitations of the study}

The retrospective nature of our study was related to the fact that we used a registry approach in the setting of no established central (nationwide) registry. Currently, few medical procedures are reported to a central registry directly after the procedure is performed. In Poland, such reporting is obligatory only for invasive cardiac procedures. The registry included 17 centres, and thus not all echocardiographic laboratories performing SE examinations in Poland were involved. However, these were the leading ones, participating in the survey internationally acclaimed, represented almost all Polish university centres, and therefore they may be considered a representative sample. There is a large variation between centres in the number of performed SE examinations. The reason for this is probably the small number of cardiologists experienced in SE along with a wide availability of coronary angiography in Poland. The small number of SE examinations performed in the centre, however, does not mean the lack of experience of the echocardiographer, who often performs SE examinations elsewhere. The numbers of SE studies performed in each centre reflect differences in interest in SE across Polish centres. In our opinion, this imaging method is still seriously underused in Poland although leaders in this field exist, mostly in the university hospitals.
An ultrasound contrast medium was used occasionally in two centres. Contrast agents are not reimbursed in Poland, and thus the high cost of the echo contrast in Poland makes it unavailable for practical use in Polish echocardiography laboratories. Patients with poor image quality (poor left ventricle opacification) were excluded from SE. Novel techniques were also occasionally used in addition to the standard SE protocol. The questionnaire did not include questions related to the application of two-dimensional/three-dimensional strain imaging, contrast echo, and other non-invasive imaging methods (e.g. SPECT).

\section{CONCLUSIONS}

1. All surveyed echocardiographic laboratories performed SE examinations to evaluate both CAD and VHD, and the majority of them used at least two types of tests.

2. Stress echocardiography is a safe diagnostic method, and major complications are very rare during evaluation of CAD and only occasionally during evaluation of VHD. It seems reasonable to run SE complication registries in each echocardiographic laboratory.

3. More than half of exercise SE examinations were performed in the hospital setting, while pharmacological stress testing was more commonly performed on an outpatient basis.

4. Despite the European recommendations, SE examinations to evaluate CAD are performed less frequently than electrocardiographic exercise tests, although they already represent a significant proportion of all stress tests in Poland. It seems reasonable to promote SE for the evaluation of both CAD and VHD.

\section{Conflict of interest: none declared}

\section{References}

1. Bhattacharyya S, Chehab O, Khattar R, et al. Stress echocardiography in clinical practice: a United Kingdom National Health Service Survey on behalf of the British Society of Echocardiography. Eur Heart J Cardiovasc Imaging. 2014; 15(2): 158-163, doi: 10.1093/ehjci/jet082, indexed in Pubmed: 23907344.

2. Płońska Gościniak E, Gackowski A, Gąsior Z, et al. [Recommendations of the Echocardiography Working Group of the Polish Cardiac Society for stress echocardiography use in clinical practice 2011]. Kardiol Pol. 2011; 69(6): 642-648, indexed in Pubmed: 21678317.

3. Lancellotti P, Płońska-Gościniak E, Garbi M, et al. Cardiovascular imaging practice in Europe: a report from the European Association of Cardiovascular Imaging. Eur Heart J Cardiovasc Imaging. 2015; 16(7): 697-702, doi: 10.1093/ehjci/jev116, indexed in Pubmed: 25944050.

4. Kolh P, Windecker S, Alfonso F, et al. 2014 ESC/EACTS Guidelines on myocardial revascularization: the Task Force on Myocardial Revascularization of the European Society of Cardiology (ESC) and the European Association for Cardio-Thoracic Surgery (EACTS). Developed with the special contribution of the European Association of Percutaneous Cardiovascular Interventions (EAPCI). Eur J Cardiothorac Surg. 2014; 46: 517-592, doi: 10.1093/eurheartj/ehu278. 
5. Sicari R, Nihoyannopoulos P, Evangelista A, et al. Stress Echocardiography Expert Consensus Statement--Executive Summary: European Association of Echocardiography (EAE) (a registered branch of the ESC). Eur Heart J. 2008; 30(3): 278-289, doi: 10.1093/eurheartj/ehn492.

6. Marangelli V, Iliceto S, Piccinni G, et al. Detection of coronary artery disease by digital stress echocardiography: comparison of exercise, transesophageal atrial pacing and dipyridamole echocardiography. J Am Coll Cardiol. 1994; 24(1): 117-124, indexed in Pubmed: 8006254.

7. Shah BN, Balaji G, Alhajiri A, et al. Incremental diagnostic and prognostic value of contemporary stress echocardiography in a chest pain unit: mortality and morbidity outcomes from a real-world setting. Circ Cardiovasc Imaging. 2013; 6(2): 202-209, doi: 10.1161/CIRCIMAGING.112.980797, indexed in Pubmed: 23258477.

8. Plana JC, Mikati IA, Dokainish H, et al. A randomized cross-over study for evaluation of the effect of image optimization with contrast on the diagnostic accuracy of dobutamine echocardiography in coronary artery disease The OPTIMIZE Trial. JACC Cardiovasc Imaging. 2008; 1(2): 145-152, doi: 10.1016/j.jcmg.2007.10.014, indexed in Pubmed: 19356420.

9. Senior R, Becher H, Monaghan M, et al. Contrast echocardiography: evidence-based recommendations by European Association of Echocardiography. Eur J Echocardiogr. 2009; 10(2): 194-212, doi: 10.1093/ejechocard/jep005, indexed in Pubmed: 19270054.

10. Magne J, Lancellotti P, Piérard LA. Exercise-induced changes in degenerative mitral regurgitation. J Am Coll Cardiol. 2010; 56(4): 300-309, doi: 10.1016/j.jacc.2009.12.073, indexed in Pubmed: 20633822.

11. Montalescot G, Sechtem U, Achenbach S, et al. 2013 ESC guidelines on the management of stable coronary artery disease: the Task Force on the management of stable coronary artery disease of the European Society of Cardiology. Eur Heart J. 2013; 34(38): 2949-3003, doi: 10.1093/eurheartj/eht296, indexed in Pubmed: 23996286.
12. Kim MN, Kim SA, Kim YH, et al. Head to Head Comparison of Stress Echocardiography with Exercise Electrocardiography for the Detection of Coronary Artery Stenosis in Women. J Cardiovasc Ultrasound. 2016; 24(2): 135-143, doi: 10.4250/jcu.2016.24.2.135, indexed in Pubmed: 27358706.

13. Pibarot P, Dumesnil J. Low-Flow, low-gradient aortic stenosis with normal and depressed left ventricular ejection fraction. J Am Coll Cardiol. 2012; 60(19): 1845-1853, doi: 10.1016/j. jacc.2012.06.051.

14. Blais C, Burwash IG, Mundigler G, et al. Projected valve area at normal flow rate improves the assessment of stenosis severity in patients with low-flow, low-gradient aortic stenosis: the multicenter TOPAS (Truly or Pseudo-Severe Aortic Stenosis) study. Circulation. 2006; 113(5): 711-721, doi: 10.1161/CIRCULATIONAHA.105.557678, indexed in Pubmed: 16461844.

15. Vahanian A, Alfieri O, Andreotti F, et al. Guidelines on the management of valvular heart disease (version 2012). Eur Heart J. 2012; 33(19): 2451-2496, doi: 10.1093/eurheartj/ehs109, indexed in Pubmed: 22922415.

16. Geleijnse ML, Krenning BJ, Nemes A, et al. Incidence, pathophysiology, and treatment of complications during dobutamine-atropine stress echocardiography. Circulation. 2010; 121(15): 1756-1767, doi: 10.1161/CIRCULATIONAHA.109.859264, indexed in Pubmed: 20404267.

17. Płońska E, Szwed H, Gasior Z, et al. [Side effects during dobutamine stress echocardiography: analysis of 582 studies]. Pol Merkur Lek. 1999; 7(40): 164-168, indexed in Pubmed: 10835905.

18. Weidmann B, Lepique CU, Jansen W, et al. Myocardial infarction as a complication of dobutamine stress echocardiography. J Am Soc Echocardiogr. 1997; 10(7): 768-771, doi: 10.1016/S0894-7317(97)70124-X, indexed in Pubmed: 9339432.

19. De Sutter J, Poldermans D, Vourvouri E, et al. Long-term prognostic significance of complex ventricular arrhythmias induced during dobutamine stress echocardiography. Am J Cardiol. 2003; 91(2): 242-244, doi: 10.1016/S0002-9149(02)03118-1, indexed in Pubmed: 12521644.

Cite this article as: Płońska-Gościniak E, Kasprzak JD, Olędzki S, et al. Polish Stress Echocardiography Registry (Pol-STRESS registry) - a multicentre study. Stress echocardiography in Poland: numbers, settings, results, and complications. Kardiol Pol. 2017; 75(9): 922-930, doi: 10.5603/KP.a2017.0121. 


\title{
Polski Rejestr Echokardiograficznych Badań Obciążeniowych (Pol-STRESS) — badanie wieloośrodkowe. Echokardiografia obciążeniowa w Polsce: liczby, rezultaty i powikłania
}

\author{
Edyta Płońska-Gościniak ${ }^{1}$, Jarosław D. Kasprzak², Szymon Olędzki ${ }^{1}$, Jolanta Rzucidło-Resil ${ }^{3}$, \\ Piotr Gościniak ${ }^{4}$, Tomasz Kukulski ${ }^{5}$, Katarzyna Mizia-Stec ${ }^{6}$, Wojciech Kosmala ${ }^{7}$, Dariusz Kosior ${ }^{8}$, \\ Marta Marcinkiewicz-Siemion ${ }^{9}$, Barbara Brzezińska ${ }^{10}$, Beata Zaborska ${ }^{11}$, Marcin Fijałkowski ${ }^{12}$, \\ Iwona Świątkiewicz ${ }^{13}$, Andrzej Szyszka ${ }^{14}$, Jan Błażejewski ${ }^{15}$, Wojciech Witkiewicz ${ }^{1}$, \\ Danuta Sorysz ${ }^{16}$, Agnieszka Olszanecka ${ }^{17}$, Zbigniew Gąsior ${ }^{5}$
}

${ }^{1}$ Koordynator; Klinika Kardiologii, Pomorski Uniwersytet Medyczny, Szczecin; ${ }^{2}$ Klinika Kardiologii, Uniwersytet Medyczny, Łódź; ${ }^{3}$ Klinika Chorób Wieńcowych, Szpital im. Jana Pawła II, Collegium Medicum Uniwersytet Medyczny, Kraków; ${ }^{*}$ Klinika Kardiologii, Szpital Wojewódzki, Szczecin; ${ }^{5}$ Klinika Kardiologii, Śląski Uniwersytet Medyczny w Katowicach, Śląskie Centrum Chorób Serca, Zabrze; ${ }^{6}$ Klinika Kardiologii, Wydział Lekarski w Katowicach, Śląski Uniwersytet Medyczny, Katowice; ${ }^{7}$ Klinika Kardiologii, Uniwersytet Medyczny, Wrocław; ${ }^{8}$ Klinika Kardiologii, Centralny Szpital Uniwersytecki, Warszawa; ${ }^{9}$ Klinika Kardiologii, Uniwersytet Medyczny, Białystok; ${ }^{10}$ Klinika Kardiologii, Szpital im. T. Marciniaka, Wrocław; ${ }^{11}$ Klinika Kardiologii, Centrum Medycznego Kształcenia Podyplomowego, Szpital Grochowski, Warszawa; ${ }^{12}$ I Klinika Kardiologii, Gdański Uniwersytet Medyczny, Gdańsk; ${ }^{13}$ Klinika Kardiologii i Medycyny Wewnętrznej, Uniwersytet im. M. Kopernika, Collegium Medicum, Bydgoszcz; ${ }^{14} \mid$ II Klinika Kardiologii, Uniwersytet Medyczny, Poznań; ${ }^{15} \mid$ Katedra Kardiologii, Uniwersytet im. M. Kopernika, Collegium Medicum, Bydgoszcz; ${ }^{16}$ |l Klinika Kardiologii, Collegium Medicum Uniwersytet Jagielloński, Kraków; ${ }^{17}$ I Klinika Kardiologii, Elektrokardiologii Interwencyjnej i Nadciśnienia Tętniczego, Collegium Medicum Uniwersytet Jagielloński, Kraków

\section{Streszczen ie}

Wstęp: Echokardiografia obciążeniowa jest powszechnie stosowana w Europie. Dotychczas nie było dostępnych zbiorczych danych na temat wykonywania echokardiograficznych testów obciążeniowych w Polsce.

Cel: Celem niniejszej pracy była analiza liczby wykonywanych obciążeniowych badań echokardiograficznych w Polsce, trybu ich wykonywania, ich wyników oraz związanych z nimi powikłań.

Metody: Uniwersyteckie i duże centra kardiologiczne na terenie Polski poproszono o retrospektywne wypełnienie ankiet dotyczących przeprowadzania echokardiograficznych badań obciążeniowych w okresie od 1 maja 2014 r. do 1 maja 2015 r. Wyniki: Do badania włączono dane z 17 ośrodków, w których przeprowadzono 4611 echokardiograficznych prób obciążeniowych, w tym 4408 testów w ramach diagnostyki choroby wieńcowej oraz 203 prób oceniających wady serca. W zakresie oceny choroby wieńcowej wszystkie ośrodki wykonywały próbę z dobutaminą (100\%), 10 (58,8\%) ośrodków test z szybką stymulacją serca, test wysiłkowy na cykloergometrze i na bieżni był przeprowadzany w odpowiednio $6(35,3 \%)$ i 5 (29,4\%) ośrodkach. Jeden (0,59\%) ośrodek wykonywał test z dipiridamolem. Wszystkie (100\%) badane pracownie oceniały niskogradientową niskoprzepływową stenozę aortalną, w 8 (47\%) ośrodkach diagnozowano bezobjawową stenozę aortalną i także w $8(47 \%)$ - ocenę niedomykalności mitralnej. Liczba wykonywanych badań w polskich ośrodkach wynosiła średnio $271 /$ rok. Większość centrów przeprowadzała ponad 100 badań rocznie (64,7\%). Nie stwierdzono zgonu w trakcie echokardiografii obciążeniowej w ankietowanych ośrodkach. U 3 (0,07\%) pacjentów wystapił zawał serca. Czestoskurcz komorowy nieutrwalony stwierdzono w trakcie $52(1,1 \%)$ badań. Częstość łagodnych powikłań była niska. W diagnostyce choroby wieńcowej test wysiłkowy na cykloergometrze $(72,6 \%)$, test wysiłkowy na bieżni $(87,6 \%)$ i test z dobutaminą małej dawki $(68,0 \%)$ wykonywano częściej w ramach hospitalizacji, a częściej w trybie ambulatoryjnym zanotowano test z dipirydamolem (77,6\%). Nie było istotnych różnic w zakresie liczby badań przeprowadzanych w trybie ambulatoryjnym i w czasie hospitalizacji dla testu z dobutamina dużej dawki oraz ze stymulacją serca. Testy zastosowane w diagnostyce wad serca częściej wykonywano w ramach hospitalizacji. W analizowanym okresie w rejestrowanych ośrodkach echokardiografia obciążeniowa stanowiła ponad jedną trzecią testów obciążeniowych.

Wnioski: Echokardiografia obciążeniowa jest badaniem bezpiecznym. Istotne powikłania występują bardzo rzadko. Mimo rekomendacji europejskich echokardiograficzne testy obciążeniowe w diagnostyce choroby wieńcowej są wykonywane rzadziej niż elektrokardiograficzny test wysiłkowy, choć stanowią już znaczny odsetek testów obciążeniowych. Wydaje się, że jest wskazana szersza promocja echokardiografii obciążeniowej zarówno w celu oceny choroby wieńcowej, jak i wad serca. Słowa kluczowe: echokardiografia obciążeniowa, wady serca, choroba wieńcowa

Kardiol Pol 2017; 75, 9: 922-930 